\title{
Research on the Development Status and Countermeasures of College Students' Innovation and Entrepreneurship Information Platform
}

\author{
Weiwei Yi, Taowen Zhuang \\ ChongQing Institute of Engineering \\ ChongQing, China \\ 21461619@qq.com
}

\begin{abstract}
College students' innovative entrepreneurial platform, which combined with investment, industry, scientific research, colleges and universities, markets and other resources, provides the full services for the college students' innovative undertaking. In spite of the remarkable achievements of innovation and entrepreneurship platform of college students, there are still some problems existing in the platform operation. This paper analyzes the platform development situation and countermeasures from the aspects of platform usage, operation and organization system for the creation of an innovative entrepreneurial platform conform to the professional characteristics of the university, the promotion of the college students' innovative undertaking, and even the whole innovationdriven development.
\end{abstract}

Keywords-College

Innovation;

Entrepreneurship; Information platform

\section{INTRODUCTION}

College students' innovative entrepreneurial platform for college students, combined with investment, industry, scientific research, colleges and universities, the market of various resources, such as for the college students' innovative undertaking provides the omni-directional service, by strengthening business training and guidance, to enhance students' innovative entrepreneurial knowledge and ability. From 2015, premier li keqiang put forward the goal of "mass entrepreneurship and innovation", and now the innovation and entrepreneurship platform of college students has developed greatly. According to the type division, can be divided into three types, one is the facility equipment platform represented by the training center; the second is the education practice platform represented by the crowd creation space; Third, internet-based information service platform. Compared with these three platforms, the information platform has a wider range of benefits, more sustainable and more flexible. On the one hand, it can provide a one-stop service for college students to transform the whole cycle from innovation and entrepreneurship to business achievements. It across time and space, on the other hand, the information resource integration ability, to colleges and universities of professional whole ecology, the establishment of three-dimensional curriculum system in colleges and universities of professional talent training type of analysis and research of the colleges and universities of professional disciplines and the construction of the local industry supply and demand, schools and local cultural industry can be integrated with development, entrepreneurship, employment training program on graduates who major in colleges and universities in the operation and implementation, to the cultivation of talents and training and so on all has the profound significance.

Innovation is the driving force of national progress and national prosperity. It is the historical mission of the modern university to cultivate talents with innovative consciousness and entrepreneurial ability for the country, so the cooperation with universities is attached great importance both at home and abroad. In foreign countries, it is often used to set up funds, enterprises to fund scientific research, school-enterprise joint ventures or schools to participate in enterprise research and other forms of production and research cooperation. More successful cases is sitting silicon valley "around the island economy" mode, it near to the university as the "main island", driving the development of "ecological" cluster economy model, create a batch of have the vitality of enterprises cluster. The successful science and technology parks in Europe and America are all based on universities, which use the scientific research and talent advantages of universities to create hightech parks and give play to the radiation effects of high-tech. At home, colleges and universities have abundant talent resources and carry out the implementation environment of cooperative development of industry-university-research, with good incubation conditions. However, the time for Chinese universities to pursue innovation and entrepreneurship development is still very short, which requires a process of adaptation, learning and development. Only in-depth understanding of China's national conditions, the focus of the social structure, economic structure and industrialization, can effectively to academic is devoted to the research and application, meet the needs of society and the market, leading the thinking progress and technical updates. According to the relevant research results in China, Yang liping et al. designed the education network platform for college students' innovation and entrepreneurship based on SSH architecture. Xing chaoxia et al. proposed the idea of innovation and entrepreneurship education platform design based on the idea of e-learning; 
some scholars, such as cheng weihua and ma jie, put forward the construction of innovation and entrepreneurship knowledge base based on the ontology of education. These researches provide effective reference and support for the construction of education platform for college students' innovation and entrepreneurship. Although the achievements of innovation and entrepreneurship platform of college students are remarkable, there are still some problems in the operation of the platform.

\section{THE USE OF INNOVATION AND ENTREPRENEURSHIP INFORMATION PLATFORM IS LOW IN COLLEGES AND UNIVERSITIES.}

At present, colleges and universities are integrating and publicizing the education resources of innovation and entrepreneurship, without highlighting the advantages of informatization, and not using the function of the Internet to design an online system with time. Entrepreneurship training program, for example, almost all the innovation and expansion plans, innovative entrepreneurship competition and other information, is the school to inform the teacher, counselor or teacher again to inform students, delayed the immediacy of the students to understand information, also can't arouse the enthusiasm of students' innovative entrepreneurial. In addition, if the application to the studio, salon, etc., college students still need to fill out the paper material, and find a signature and seal of the relevant departments, the examination and approval formalities trial, intermediate process all by themselves in one place after another run, and meets the material to prepare not neat, problems such as wrong time, spend more time and energy.

Countermeasures: improve the quality of innovation and entrepreneurship information platform and expand its influence through publicity. We will establish a sharing platform for provincial, regional and inter-school innovation and entrepreneurship to maximize the energy resources. To establish the in-depth cooperation between universities, enterprises, government and intermediary organizations, increase the interests of the platform and improve the user's viscosity.

\section{THE PARTICIPATION OF MIDDLE SCHOOL STUDENTS IN INNOVATION AND ENTREPRENEURSHIP IS NOT HIGH.}

Everyone knows the importance of innovation and entrepreneurship education, and has made a lot of efforts in the construction of innovation and entrepreneurship information platform. However, there are still many teachers and students who lack sufficient understanding of innovation and entrepreneurship activities, or the spirit is willing and insufficient. On the one hand, the teacher's teaching task is heavy, not familiar with the innovation and entrepreneurship education, and does not have the condition to be promoted as the entrepreneur mentor in time and energy. On the other hand, students have a lot of work to do and more homework to finish. If they can't combine their work with innovation projects, they may have no time to think about innovation and entrepreneurship programs. School level, the corresponding policies and programmes for innovation, entrepreneurship education is in the initial stage of establishing and university students' innovative undertaking needs certain information platform construction of human and financial resources to support, otherwise can only be empty talk, but, because of colleges and universities on the college students' innovative entrepreneurial education investment co., LTD, as a result, a lot of equipment in innovation entrepreneurship education in colleges and universities lack, platform construction lag, the problem such as low resource utilization. These factors lead to insufficient innovation entrepreneurship education, students' innovative entrepreneurial experience, entrepreneurial success rate low, causing most of the students think in innovative entrepreneurial activity is a waste of time, to participate in the enthusiasm is low.

Countermeasures: innovation entrepreneurship education is a long-term work, not rely on the efforts of the short time can obtain good effect, so don't recommend some universities to the surface of the innovation result, sent too arduous task for teachers, students, eventually backfire, effect, instead more to teachers and pupils, school teachers and students should focus on cultivating the consciousness of innovation and entrepreneurship. For teachers, first of all should change teaching idea, the quality education into the teaching activities of the professional, set up "to the students for this" teaching idea, correctly guide students, cultivate the initiative of the students' development, help students to set up an innovative personality, lay a foundation for the development of the students in the future. At the same time, the school can use a variety of methods to improve the teachers' practical ability, according to the actual situation of the school and the comprehensive quality of the teachers, to make the practice opportunities for teachers. Allows teachers to participate in enterprise projects, encourage teachers take more time to accumulate practical experience, improve teachers' practical ability, encourage teachers to participate in business practice, participate in business training and business communication, improve the teachers' business quality. For students colleges and universities should carry out various innovation and entrepreneurship competition, establish open, innovative campus culture. The cultural atmosphere of the campus will directly affect the education work and students' professional study. Universities should accept the failure of the college students' innovative entrepreneurial project, not as, should make full use of these failures, let the students know the cause of the failure, feel the risk of entrepreneurship, lets the student right to face failure than the success has more far-reaching significance. 
IV. THE ORGANIZATIONAL SYSTEM OF INNOVATION AND ENTREPRENEURSHIP SYSTEM IN COLLEGES AND UNIVERSITIES IS NOT PERFECT.

National policy has been emphasized to the cultivation of college students' innovative undertaking practical ability as a measure of college talent training quality, also issued a series of related to encourage and support policies, but unfortunately, not form a unified understanding at the grass-roots level, ideology is not completely keep up with the pace of reform, the various functional departments of management power and resources scattered, not well integrated. For example, the firstline guidance teachers who guide the innovation and entrepreneurship of college students are mainly professional teachers. However, many professional teachers are not entrepreneurial teachers. The teaching and overall planning of college students' innovation and entrepreneurship courses is mainly in charge of the innovation college or the teaching department; The scientific research department is responsible for the application of science and technology projects; College students' social practice, campus culture practice and so on are mainly responsible for student management. There are too many departments involved, and if there is no sound coordination mechanism between departments, there will be difficulties in connection and integration failure.

Countermeasures: universities should increase the proportion of innovation and entrepreneurship practice in the whole teaching system, and increase the proportion of practical courses in credits. Change the traditional teaching concept, setting up more diversified practice class activities, encourage teachers' innovative teaching content and teaching methods, the traditional force-feeding teaching method into heuristic teaching, to design teaching activities according to the actual project, the original teaching content and innovation projects, improve students' ability of innovation practice. Moreover, the students' enthusiasm will be improved through community, debate, competition and so on. Set up a teaching effect evaluation system innovation and retreat from superficial evaluation, to fully demonstrate the characteristics of the entrepreneurship education practice of innovation, constantly optimize the supervision of teachers' teaching activities and management, to strengthen the supervision and administration of students' practice, the practice of using periodic reports and exhibition to examine and supervise the students' practical effect.

\section{THE UNIVERSITY INNOVATION AND ENTREPRENEURSHIP} INFORMATION PLATFORM OPERATION IS RELATIVELY ISOLATED.

Of the information service platform of innovative entrepreneurship education in colleges and universities usually adopted module includes entrepreneurial dynamic, entrepreneurial policy and project platform, data download and so on, is limited to provide certain information support for college students to carry out the innovative entrepreneurial. The guidance of the teaching staff, the channel of financial support, financing channels, loan policies, support and tracking information support have not kept up, and the information service is not fully systematized. College students in the innovative entrepreneurial activity, unable to understand the project situation in time, project processes, project case, don't even know where can get help, the school also did not carry on the omni-directional system training on college students' innovative undertaking. On the other hand, there is a single mode of innovation and entrepreneurship in colleges and universities in our country. Because the overall participation innovation of entrepreneurial activity behavior main body type single, limited number, lack of social entrepreneurship environment for innovation ambience, caused the university innovation development of entrepreneurship education shows a tendency of monologue.

Countermeasures: firstly, we should set up an innovation and entrepreneurship system with deep cooperation between government, universities and society, and establish a multilevel and diversified education mechanism to promote the allround development of innovation and entrepreneurship education. Colleges and universities should establish special departments, strengthen communication with local governments, and give full play to the role of government departments in integrating resources and policy guidance. Colleges and universities can strengthen the cooperation with enterprises, improve the level of students' entrepreneurial team and enterprise communication, introduce a large number of social forces, and promote the development of education innovation and entrepreneurship. Secondly, it is necessary to expand the source of college students' innovation and start-up capital. Capital for innovation has important influence to the success of the venture, although the government has helped students venture capital, the venture capital also has assisted students in university, but it doesn't meet the needs of college students' entrepreneurship. Therefore, colleges and universities can use the advantages of college students' entrepreneurial projects to obtain social capital support. 


\section{THE INNOVATION AND ENTREPRENEURSHIP PLATFORM LACKS PERTINENCE}

China's innovation and entrepreneurship development path is not a national general. The annual report on Chinese innovation entrepreneurship 2015 pointed out that China has a north China, east China, south China, central and western, a total of five entrepreneurship center, the more obvious features, business information platform for college students in the area of innovation put forward higher requirements.

\section{CONCLUSION}

We can introduce the concept of regionalization innovation into the thinking of college students' innovation and entrepreneurship information platform. Regional innovation system in an area for large ecological environment, universities, enterprises, research institutes, local government and intermediary agents is rooted in this area, with local, interactive learning, cooperation. The information platform of the introduction of the innovation system innovation entrepreneurship design more targeted, reducing market uncertainty, improve college students' project success rate, promote regional innovation capability and competitive advantage continuously, offset between each behavior main body in the area of technology lock-in phenomenon. The introduction of the concept of regional innovation, make the local government for the university students' innovative entrepreneurial achievements provide help and support all cycle, reduce because of the policy are not familiar with, caused by the uneven channels of innovative entrepreneurial frustrating problem. By local enterprises to enter a project in colleges and universities, colleges and universities output project to the society, between the enterprise and college students set up project of supply and demand of the two-way communication platform, to ensure that the theoretical results to the business transformation through sex, promote students' learning interest, realize the actual project into the classroom, contribute to the establishment of a three-dimensional ecological curriculum system.

As an important national strategy, innovation-driven development has become a key supporting factor leading to economic transformation. The construction of college students' innovation and entrepreneurship platform plays an important role in it. It provides a platform for the integration and development of institutional and local cultural industries, and helps colleges and universities to understand the market more deeply and provide the basis for the development and adjustment of the training programs for university professionals. Starting a business is not only a supplement to employment, but also a high-quality job. In order to improve the quality of college students' innovative undertaking, try to reduce unnecessary failure, to a certain degree of college students ability training and education, under the background of current social various colleges and universities is an urgent need to solve realistic problems. Make a batch of accords with college students, the school specialized characteristic features such as platform for innovation, to promote college students' innovative undertaking, and even the whole innovation driven development, has the very vital significance.

\section{REFERENCES}

[1] Liu swen. Precision culture: the difficulty of cracking Open University students' innovation and entrepreneurship (education) [J]. Chinese university science and technology, 2016(9).

[2] Shao huanju. Research on the construction of education platform for innovation and entrepreneurship in universities embedded with "Internet plus" [J]. Education modernization, 2016(9).

[3] Huang beng, huang rui. Literature review on the construction of innovation and entrepreneurship practice platform for college students [J]. Productivity research, 2014(1).

[4] Yang liping, wang wei, zeng huarong. Design of education network platform for college students based on SSH architecture [J]. Software guide,2011,(6) 